\title{
AKULTURASI DALAM TRADISI LISAN MACA SYEKH DI KABUpATEN PANDEGLANG
}

\author{
THE ACCULTURATION IN ORAL TRADITION OFMACA SYEKH \\ IN PANDEGLANG DISTRICT
}

\author{
Irvan Setiawan \\ Balai Pelestarian dan Nilai Budaya Jawa Barat \\ Jl. Cinambo No. 136 Ujungberung - Bandung \\ e-mail: kamaliasetiawan@yahoo.co.id
}

DOI: 10.30959/patanjala.v11i1.481

\begin{abstract}
Abstrak
Tradisi lisan Maca Syekh di Kabupaten Pandeglang Provinsi Banten merupakan salah satu bentuk pengajaran yang memiliki tujuan untuk mendengar dan memahami riwayat hidup sosok Syekh Abdul Qadir Jaelani sebagai salah satu tokoh penyebar agama Islam. Hal menarik untuk diteliti dari tradisi lisan Maca Syekh adalah adanya sebuah proses akulturasi dengan melibatkan unsur budaya, agama, dan unsur politik untuk kemudian menghasilkan sebuah produk akulturasi yang dapat bertahan hingga kini. Penelitian deskriptif dengan mengacu pada data kualitatif merupakan pilihan tepat mengingat sumber data yang dicari adalah informasi essay yang banyak membutuhkan analisa kualitatif. Dari hasil analisa diketahui bahwa akulturasi dari tradisi lisan Maca Syekh di Kabupaten Pandeglang Provinsi Banten terbagi menjadi dua yaitu akulturasi tradisi dan akulturasi kebahasaan. Unsur politik dideskripsikan secara singkat karena hanya melibatkan penggunaan huruf Arab dalam penulisan Maca Syekh yang pada masa Penjajahan menjadi sebuah hal yang dianggap mewakili kalangan modernis.
\end{abstract}

Kata kunci: Maca Syekh, tradisi lisan.

\section{Abstract}

Maca Syekh oral tradition in Pandeglang Regency, Banten Province, is one form of teaching that aims to hear and understand the life history of Sheikh Abdul Qadir Jaelani. An interesting thing to examine from Maca Shaykh's oral tradition is the existence of an acculturation process involving elements of culture, religion, and political elements to then produce an acculturation product that can survive until now. Descriptive research with reference to qualitative data is the right choice considering the source of the data sought is essay information which requires a lot of qualitative analysis. From the results of the analysis, it is known that the acculturation of the Maca Shaykh oral tradition in Pandeglang Regency, Banten Province, is divided into two: traditional acculturation and linguistic acculturation. The political element is described briefly because it only involves the use of Arabic letters in the Maca Syekh writing which in the colonial period became something considered to represent modernists.

Keywords: Maca Syekh, oral tradition.

\section{A. PENDAHULUAN}

Kebudayaan merupakan bagian yang tidak terpisahkan dalam kehidupan manusia. Perilaku terstruktur baik yang disadari maupun tidak disadari manusia membuktikan bahwa ia telah masuk dalam sebuah lingkungan kebudayaan. Terlebih lagi apabila individu atau masyarakat mulai menyelami tentang makna dan nilai dari apa yang telah dilakukannya setelah sekian lama bersentuhan dengan kebudayaan.

Dikaitkan intangible culture heritage (warisan budaya takbenda), nilai dari sebuah karya budaya tidak hanya dilihat dari segi fisiknya saja. Karinding 
misalnya, sebuah waditra (peralatan seni musik) yang ada di wilayah tatar Sunda akan tampak identitasnya tatkala dibunyikan. Terlebih lagi apabila menyimak alunan suara yang dihasilkan karinding. Tentunya, akan ada makna dan nilai tersendiri di benak pendengar apabila menyimak dengan seksama untuk kemudian berpengaruh pada emosi ataupun rasa. Contoh tersebut setidaknya dapat menjelaskan bahwa sebuah karya budaya tidak hanya ditinjau dari apa yang ditangkap oleh indera manusia. Ada nilai dan makna tentang berbagai aspek tentang kehidupan yang terkandung dalam sebuah karya budaya tersebut.

Karya budaya yang sudah mengalami proses regenerasi dan memiliki nilai luhur kemudian menjadi sebuah warisan budaya yang terpilah menjadi dua bagian, yaitu Warisan Budaya Takbenda (intangible heritage) dan Warisan Budaya Benda (tangible heritage) ${ }^{1}$.

Ide dari penciptaan sebuah warisan budaya dalam pemahaman masyarakat umum tidaklah berjalan tanpa diiringi dengan pengetahuan yang melatarbelakanginya. Pengetahuan tersebut diperoleh melalui proses belajar dari apa yang ada di lingkungan sekitarnya lalu disinergikan. Hasilnya adalah sebuah formulasi yang menjadi dasar dari sebuah warisan budaya.

Tradisi lisan yang menjadi bagian dari warisan budaya takbenda merupakan sebuah kompleksitas pengetahuan tentang beberapa unsur pengetahuan yang disatukan dengan memiliki tujuan menyebarluaskan informasi terkait dengan konteks pada zamannya. Sebagai salah satu warisan budaya takbenda, tradisi lisan memiliki kandungan nilai budaya luhur melalui kisah-kisah yang dipaparkan dengan variasi lantunan nada yang

\footnotetext{
${ }^{1}$ Direktorat Warisan dan Diplomasi Budaya menetapkan bahwa yang disebut sebagai warisan budaya takbenda adalah kekayaan budaya takbenda minimal telah berusia 50 tahun dan telah dilakukan minimal oleh dua generasi.
}

disesuaikan dengan karakter masyarakat pendukungnya.

Beranjak dari nilai positif dari fungsi tradisi lisan, hingga saat ini bidang karya budaya tersebut secara umum masih belum begitu diperhatikan untuk dilestarikan. Hal demikian mengakibatkan sedikit demi sedikit karya budaya yang termasuk dalam bidang tradisi dan ekspresi lisan semakin terancam punah atau bahkan telah punah.

Maca Syekh, salah satu warisan budaya takbenda yang masuk dalam bidang tradisi dan ekspresi lisan yang ada di Kabupaten Pandeglang Provinsi Banten misalnya, saat ini juga tengah menghadapi kepunahan. Hudaeri dkk (2007: 10) menekankan bahwa cerita-cerita yang ada dalam manaqib (Maca Syekh) bertujuan memberikan arahan yang bersifat moral kepada manusia tentang bagaimana mesti bertindak dalam kehidupan di dunia ini. Selain itu, ada sisi keragaman budaya yang diramu sedemikian rupa sehingga tercipta sebuah akulturasi yang diwujudkan dalam sebuah karya budaya bidang tradisi lisan yang bernama Maca Syekh.

Bertitik tolak dari tersinerginya agama dan budaya dalam sebuah warisan budaya takbenda, Maca Syekh menjadi sebuah masalah menarik untuk dikaji terutama dari sudut pandang memaknai akulturasi pada karya budaya.

Berdasarkan permasalahan tersebut, penelitian ini bertujuan untuk mengungkap salah satu keragaman budaya yang diwujudkan dalam sebuah tradisi lisan. Selain itu, penelitian ini juga diharapkan dapat memberikan wawasan baru akan pentingnya sebuah akulturasi terutama pada masyarakat di Kabupaten Pandeglang.

Beberapa batasan pengertian sebagai ruang lingkup penelitian ini meliputi: akulturasi, nilai, norma, tradisi lisan, dan Maca Syekh.

\section{- Akulturasi}

Menurut Koentjaraningrat (1990: 248), akulturasi adalah sebuah proses sosial yang timbul apabila suatu kelompok 
manusia dengan suatu kebudayaan tertentu dihadapkan dengan unsur-unsur dari suatu kebudayaan asing sehingga unsur-unsur kebudayaan asing lambat laun diterima dan diolah ke dalam kebudayaan sendiri tanpa menyebabkan hilangnya kepribadian kebudayaan itu sendiri.

\section{- Tradisi Lisan}

Menurut Sedyawati (1996: 5), tradisi lisan adalah "segala wacana yang disampaikan secara lisan, mengikuti cara atau adat istiadat yang telah memola alam suatu masyarakat". Ditambahkan oleh Hutomo (1991: 11) bahwa tradisi lisan mencakup beberapa hal meliputi kesusastraan lisan, teknologi tradisional, pengetahuan masyarakat, religi dan kepercayaan masyarakat, kesenian, dan hukum adat.

\section{- Nilai}

Nilai adalah segala sesuatu yang dipentingkan manusia sebagai subjek, menyangkut segala sesuatu yang baik atau buruk sebagai abstraksi, pandangan, atau maksud dari berbagai pengalaman dengan seleksi perilaku yang ketat. Dalam kehidupan masyarakat, nilai menjadi semacam acuan untuk memberikan tanggapan atas perilaku, tingkah laku, dan segala sesuatu yang berkaitan dengan aktivitas masyarakat baik secara kelompok maupun individu. Nilai yang muncul tersebut dapat bersifat positif apabila akan berakibat baik, namun akan bersifat negatif jika berakibat buruk pada objek yang diberikan nilai.

Nilai merupakan konsepsi yang dapat bersifat eksplisit, dapat pula bersifat implisit, jadi dapat nampak dalam perbuatan ada pula yang sifatnya hanya satu kecenderungan (potensi) untuk berbuat. Selain itu, nilai juga merupakan sebuah keyakinan dan sebagai standar sikap yang relatif konsisten sehingga berhubungan dengan perbuatan, tindakan atau cara bertingkah laku.

\section{- Norma}

Menurut Harwantiyoko dan Neltje F. Katuuk (1992: 51), Norma adalah patokan perilaku dalam suatu kelompok tertentu yang memungkinkan seseorang untuk menentukan terlebih dahulu bagaimana tindakannya itu akan dinilai oleh orang lain. Norma juga merupakan kriteria bagi orang lain untuk mendukung atau menolak perilaku seseorang. Berkaitan dengan norma sosial, Emile Durkheim dalam Harwantiyoko dan Neltje F. Katuuk (1992: 51) mengatakan bahwa norma sosial adalah sesuatu yang berada di luar individu yang membatasi diri mereka dalam berperilaku. Norma yang berlaku dalam sebuah masyarakat memiliki kekuatan pengikat yang berbeda dan disesuaikan menurut tingkatannya, meliputi: cara (usage), kebiasaan (folkways), tata kelakuan (mores), dan adat istiadat (custom).

\section{- Maca Syekh}

Maca Syekh adalah salah satu kekayaan budaya bidang tradisi lisan yang sudah sejak lama ada dan hingga kini dilaksanakan oleh masyarakat Pandeglang Provinsi Banten.

\section{B. METODE PENELITIAN 1. Metode dan Analisa Data}

Sebuah penelitian memerlukan datadata yang diperoleh dengan menggunakan teknik pengumpulan data dan metode penelitian. Mengingat esensi penelitian ini bersifat deskriptif sekaligus melihat ragam akulturasi tradisi lisan Maca Syekh maka metode penelitian yang digunakan adalah metode deskriptif menggunakan analisa kualitatif.

Penelitian yang bersifat deskriptif ini berupaya mendeskripsikan dan menganalisa beberapa permasalahan sebagai berikut:

1. Pelaksanaan tradisi lisan Maca Syekh.

2. Akulturasi ditinjau unsur tradisi lisan dan bahasa.

Penggunaan analisa kualitatif membutuhkan data-data kualitatif, yaitu 
data yang berwujud pertanyaan atau berupa kata-kata yang biasanya diperoleh melalui proses wawancara.

\section{Pengumpulan Data}

Data yang dikumpulkan berwujud data kualitatif. Menurut Oetomo (2005:186), data kualitatif dapat dikumpulkan melalui tiga cara, yaitu :

a. Wawancara. Hasil data yang diperoleh adalah ungkapan langsung dari informan tentang pengalaman, pendapat, perasaan, dan pengetahuannya. Hal ini diperkuat oleh Ihromi (2006: 51) bahwa wawancara merupakan satu-satunya cara yang digunakan peneliti (Antropolog) untuk memperoleh keterangan tentang kejadian yang tidak dapat diamati sendiri, misalnya kejadian di masa lampau ataupun tidak boleh mengikuti sebuah ritus tertentu. Dalam Antropologi, teknik ini biasa dikenal dengan teknik etnografi.

b. Observasi langsung. Hasil yang diperoleh dari cara ini adalah rincian pengamatan tentang kegiatan, perilaku, dan tindakan individu atau sekelompok masyarakat yang terkait dengan tema kegiatan.

c. Penelaahan dokumentasi tertulis. Objek pencarian data tertulis dapat diarahkan pada cuplikan, kutipan atau penggalan catatan referensi yang tentunya berkaitan dengan kegiatan.

Untuk mendapatkan data kualitatif, penelitian ini menggunakan teknik wawancara dan penelaahan dokumentasi tertulis. Hal itu disebabkan esensi dari kajian tersebut berupa tradisi masyarakat yang dimaksud disertai uraiannya.

\section{Lokasi Penelitian}

Persebaran Tradisi Lisan Maca Syekh tersebar di wilayah Provinsi Banten, namun konsentrasi penutur Maca Syekh berada di tiga wilayah administratif, yaitu Kabupaten Tangerang, Kabupaten Lebak, dan Kabupaten Pandeglang (Paluseri, 2018: 114). Lokasi penelitian diambil di salah satu kabupaten tanpa melihat karakteristik dan intensitas keberadaan Maca Syekh di salah satu kabupaten. Oleh karena itu, lokasi penelitian yang dipilih yaitu di Kabupaten Pandeglang Provinsi Banten.

\section{HASIL DAN BAHASAN \\ 1. Gambaran Umum Lokasi Penelitian}

Secara astronomis, Kabupaten Pandeglang terletak antara 6021' - 7010' Lintang Selatan dan 104048'1046011' Bujur Timur. Batas administratif Pandeglang di sebelah utara adalah dengan Kabupaten Serang, sebelah selatan berbatasan dengan Samudera Indonesia, sebelah barat berbatasan dengan Selat Sunda, dan sebelah timur berbatasan dengan Kabupaten Lebak. Dua perbatasan pantai diartikan adanya aliran sungai yang membelah wilayah Kabupaten Pandeglang. Setidaknya ada 14 sungai di Kabupaten Pandeglang, yaitu, Sungai Cidano, Sungai Cibungur, Sungai Cisanggona, Sungai Ciliman, Sungai Cihonje, Sungai Cipunagara, Sungai Cisumur, Sungai Ciseureuhan, Sungai Cijaralang, Sungai Cikadongdong, Sungai Ciseukeut, Sungai Cimara, Sungai Cibaliung, dan Sungai Cicanta. Sementara di sisi lainnya, Kabupaten Pandeglang dihiasi oleh enam gunung, yaitu, Gunung Karang (1.778 mdpl); Gunung Pulosari (1.346 mdpl); Gunung Aseupan (1.174 mdpl); Gunung Payung (480 mdpl); Gunung Honje (620 mdpl); dan Gunung Tilu (562 mdpl).

Memiliki wilayah dengan luas 2,746,81 Km2, Kabupaten Pandeglang terbagi menjadi 35 kecamatan dengan jumlah penduduk pada tahun 2016 sebanyak 1.183.006 terdiri dari 604.603 laki-laki dan 578.403 perempuan (BPS Kab. Pandeglang, 2017: 71). Dari jumlah penduduk tersebut, sebagian besar beragama Islam. Hal ini dilihat dari ketiadaan jumlah tempat peribadatan non Islam di Kabupaten Pandeglang. (BPS Kab. Pandeglang, 2017: 168).

Dari segi kepemakaian bahasa, Provinsi Banten secara keseluruhan 
memiliki tiga bahasa, yaitu bahasa Sunda, Jawa, dan Lampung. Di Kabupaten Pandeglang, penggunaan bahasa Sunda banyak digunakan berikut dialek Sunda khas Banten. Istilah dialek tidaklah menjadi sebuah perbedaan bahasa yang signifikan karena dialek merupakan sebuah perbedaan kecil dari variasi penggunaan bahasa yang disesuaikan dengan kondisi pengucapan masyarakat setempat (Zulaeha, 2010: 1). Meski Bahasa Sunda mendominasi pola komunikasi masyarakat Pandeglang, Bahasa Jawa "Banten" juga cukup banyak dituturkan masyarakat Pandeglang. Oleh karena itu, Naskahnaskah Maca Syekh yang tersebar di Pandeglang juga diterjemahkan dalam dua bahasa tersebut dengan menggunakan huruf Arab Pegon.

Seh dalam pengertian Masyarakat Banten, ditujukan pada satu sosok bernama Syeh Abdul Qadir Jaelani. Menyimak dari sisi sejarah, kemunculan tradisi Maca Syekh lebih banyak mengarah pada penyebaran agama Islam melalui tradisi lisan dalam bentuk pembacaan riwayat hidup Syekh Abdul Qadir Jaelani.

Syekh Abdul Qadir Jaelani adalah seorang penyebar agama Islam terkenal. Dapat dikatakan demikian karena hasil karya beliau telah dipergunakan di berbagai wilayah penyebaran agama Islam di Indonesia utamanya di Pulau Jawa mulai dari ujung barat hingga ujung timur. Di ujung barat Pulau Jawa, nama Syekh Abdul Qadir Jaelani dikenal pada masyarakat Kabupaten Pandeglang sebagai penyebar agama Islam untuk kemudian dikenang dan disebarkan ajaran agamanya melalui tradisi lisan Maca Sekh.Selain di Pandeglang, tradisi Maca Sekh juga ada di wilayah ujung timur Pulau Jawa seperti di Jember dengan nama "Manaqib Syaikh Abdul Qodir Jailani" (Kumalasari, 2017: 1 - 18), dan di Surabaya dengan nama tradisi yang sama, yaitu "Manaqib Syaikh Abdul Qodir Jailani” (Dwi Aprilyanto, 2015: 119).

Tradisi lisan Maca Syekh tidak lepas dari proses penghormatan dan permintaan atas apa yang hendak diwujudkan kepada Sang Maha Kuasa melalui pembacaan kitab Syekh Abdul Jaelani. Wujud dari penghormatan tersebut merupakan sebuah kodrati dari naluri manusia yang dimulai sejak zaman dahulu (pra sejarah) terkait dengan adanya pusat kosmis yang merupakan sebuah pusat pertemuan antara dunia fisik (alam sekitar) dan non fisik (alam supranatural). Leluhur sebagai sebuah sosok yang dihormati pada zamannya menjadi simbol dari sebuah ajaran yang wajib dihormati dan ditaati baik ketika masih hidup maupun setelah meninggal.

Proses dinamisme yang berkembang menjadi animisme yang sudah ada jauh sebelum adanya agama-agama besar yang dalam hal ini adalah Islam - menjadi sebuah jalan dari proses regenerasi spiritual untuk kemudian "disempurnakan" dan pada akhirnya mengerucut pada sosok manusia yang diutus oleh Yang Maha Kuasa untuk memberitahukan akan adanya ajaran keesaan yang wajib diikuti karena adanya konsekuensi dari ketidakikutsertaan ataupun mengingkari keberadaanNya.

Hal ihwal kepatuhan terhadap sebuah ajaran agama tidaklah seragam antar wilayah persebaran karena bercampur dengan kultur dan religiusitas yang sudah ada sebelumnya. Patut digarisbawahi bahwa proses penyebaran agama dilakukan melalui berbagai cara. Salah satu cara yang dilakukan untuk menyebarkan agama Islam adalah dengan melakukan pendekatan budaya melalui unsur kesenian, seperti halnya dengan seni wayang kulit yang digunakan sebagai media penyebaran agama Islam di Demak pada Abad ke-XV (Praharani, 2007: 1 -58).

Cara lainnya adalah dengan melalui saluran perdagangan, saluran pernikahan, saluran pendidikan, dan saluran dakwah. Khusus mengenai saluran dakwah sebagai salah satu peyebaran agama Islam dilakukan oleh Wali Sanga, yaitu:

1. Maulana Malik Ibrahim atau Sunan Gresik berasal dari Persia. 
2. Sunan Ampel atau Raden Rahmat.

3. Sunan Drajat atau Syarifudin (putra Raden Rahmat)

4. Sunan Bonang atau Mahdun Ibrahim (putra Raden Rahmat)

5. Sunan Giri atau Raden Paku (murid Sunan Ampel).

6. Sunan Kalijaga atau Joko Said.

7. Sunan Kudus atau Jafar Sidiq.

8. Sunan Muri atau Raden Umar Said.

9. Sunan Gunung Jati atau Syarif Hidayatullah.

Tiga bangsa yang berpotensi menyebarkan agama Islam di Indonesia masing-masing, yaitu Gujarat, Persia, dan Bangsa Arab, memiliki pembuktian atas kedatangannya di Indonesia. Melalui berbagai saluran dan maksud kedatangan ke Indonesia, kultur dari bangsa pendatang tersebut sedikit banyak tersosialisasi pada masyarakat yang berkomunikasi secara intens. Hal ini kemudian membuat adanya perbedaan cara pandang dalam memaknai proses penyebaran Islam sebagai sebuah agama dengan sumber utama yaitu kitab suci Alquran, hadis, dan Sunnah.

Budaya di Indonesia yang pernah dipengaruhi oleh budaya India dengan ajaran Hindu Budhanya memberikan peluang unsur "keajaiban" untuk masuk dalam strategi penyebaran agama Islam. Oleh karena itu, Mahjudin (1991: 93) berpendapat bahwa strategi yang mendapat tempat dalam menyebarkan Islam di Indonesia adalah strategi tassawuf, yaitu sebuah ajaran berbentuk tarekat yang lebih mengandalkan gerak ruhaniah daripada gerak batiniah. Menurut Ibnu Khaldun (dalam Hamka, 1996: 2), Tasawuf merupakan ilmu syariah yang timbul kemudian di dalam agama (Islam). Diawali dengan tekun beribadah dan memutuskan pertalian dengan segala selain Allah semata. Ajaran tasawuf menolak hiasanhiasan dunia, serta membenci perkaraperkara yang selalu memperdaya orang banyak. Pengikut tasawuf lebih banyak menjauhi segala bentuk harta-benda dan kemegahan dengan cara menyendiri menuju jalan Tuhan dalam khalwat dan ibadah. Beberapa tokoh tassawuf cukup terkenal di Indonesia di antaranya Hamzah Fansuri, Nuruddin ar-Raniri, Abdurrauf Singkel, Samsudin Sumatrani, alPalimbani. Lima tokoh tassawuf tersebut banyak berkiprah menyebarkan Islam di Pulau Sumatra. Sementara untuk Pulau Jawa lebih banyak dilakukan oleh Wali Songo (wali sembilan).

Kesuksesan menyebarkan agama Islam yang dilakukan Wali Songo lebih diawali dengan sembilan sosok wali tersebut yang menurut masyarakat - kala itu - memiliki karomah yang terletak pada kekeramatan, dan penguasaan ilmu (pengetahuan, keagamaan, dan kebatinan) yang sangat tinggi. Uniknya, posisi pada tingkat kedigjayaan baik dalam bentuk keramat ataupun penguasaan ilmu selalu dicari siapa yang paling tinggi. Kala Wali Songo berhasil menyebarkan Islam di seantero Pulau Jawa, status kekeramatan dan penguasaan keilmuan Wali Songo pada beberapa lokasi di Pulau Jawa bukan menempati urutan tertinggi. Dengan demikian, status Wali Songo hanyalah dianggap sebagai "pembawa pesan Islam", sedangkan tingkat kekeramatannya dan pengusaan ilmu bukanlah yang tertinggi.

Pencarian sosok ulama yang memiliki tingkat "keajaiban" tertinggi pada masyarakat di Pulau Jawa kemudian jatuh pada sosok bernama Syekh Abdul Qadir Jaelani (1077-1166 M). Ulama yang terkenal dalam dunia tarekat dan sufisme ini lahir di Provinsi Mazandaran di Iran memberikan pengaruh sangat besar dalam dunia Islam dan bahkan mendapatkan gelar "Wali" dari masyarakat muslim di Benua India. Muslim Negara Pakistan dan India bahkan memberinya gelar Ghaus-e-Azam. Begitu halnya di India, begitu pula halnya di Indonesia (Pulau Jawa) yang juga mengkultuskan Sosok Syekh Abdul Qadir Jaelani sebagai seorang sufi yang penuh dengan keajaiban-keajaiban, keluarbiasaan, dan kesaktian. Harapan memperoleh keajaiban dan keluarbiasaan Syekh Abdul Qadir Jaelani diyakini dapat diperoleh 
melalui pelajaran tasawuf dengan sumber utama yang berasal dari kitab manaqib Syekh Abdul Qadir Jaelani.

\section{Akulturasi dalam Maca Syekh}

Direktorat Jenderal Kebudayaan, Kementerian Pendidikan dan Kebudayaan sebagai lembaga pemerintah membuat pilahan besar kebudayaan, yaitu budaya benda (tangible culture) dan budaya takbenda (intangible culture). Proses pemaknaan dan nilai yang terkandung dapat ditemukan dalam dua pilahan besar budaya tersebut. Walaupun demikian, dilihat dari segi aktivitas budaya, karya budaya takbenda nampak sangat jelas terlihat.

Intangible culture terbagi dalam beberapa bidang. Dalam Pasal 2 Ayat 1 dan 2 Konvensi 2003 UNESCO dijelaskan bahwa budaya takbenda dapat diwariskan sehingga penamaannya menjadi warisan budaya takbenda yang terbagi dalam lima bidang, yaitu:

a) tradisi dan ekspresi lisan, termasuk bahasa sebagai wahana warisan budaya takbenda;

b) seni pertunjukan;

c) adat istiadat masyarakat, ritus, dan perayaan-perayaan;

d) pengetahuan dan kebiasaan perilaku mengenai alam dan semesta;

e) kemahiran kerajinan tradisional. (Waluyo, 2009: 13)

Definisi dari warisan budaya takbenda adalah segala praktik, representasi, ekspresi, pengetahuan, keterampilan serta alat-alat, benda (alamiah), artefak dan ruang-ruang budaya terkait dengannya yang diakui oleh berbagai komunitas, kelompok, dan dalam hal tertentu perseorangan sebagai bagian warisan budaya mereka. Warisan budaya takbenda ini, yang diwariskan dari generasi ke generasi, senantiasa diciptakan kembali oleh berbagai komuniti dan kelompok sebagai tanggapan mereka terhadap lingkungannya, interaksinya dengan alam, serta sejarahnya, dan memberikan mereka rasa jati diri dan keberlanjutan, untuk menghormati keanekaragaman budaya dan daya cipta insani (Waluyo, 2009: 13).

Dalam lima bidang Warisan Budaya Takbenda, seni pertunjukan merupakan salah satu identitas budaya yang cukup mencolok. Hal demikian dilatarbelakangi oleh sudah cukup banyaknya nama kesenian yang sudah sangat umum terdengar di telinga masyarakat Indonesia. Sehingga, apabila kita mendengar nama kesenian jaipong, misalnya, maka ingatan kita akan asal lokasi wilayah jaipong mengarah ke Provinsi Jawa Barat. Begitu juga halnya dengan ondel-ondel yang akan mengarahkan ingatan kita pada asal wilayahnya yaitu DKI Jakarta.

Berpijak pada ketenaran beberapa nama karya budaya tertentu. Bidang kebudayaan lainnya yang tidak kalah pentingnya yaitu tradisi dan ekspresi lisan. Sebuah karya budaya yang lebih banyak berkecimpung dalam pengajaran tentang nilai dan makna kehidupan. Pola pengajaran dalam bidang karya budaya tersebut disebabkan oleh adanya interaksi. Bentuk interaksi tersebut dijelaskan oleh Endraswara (2013: 70) yang mengatakan bahwa tradisi lisan adalah tradisi komunikasi langsung yang memungkinkan terjadinya interaksi antara pengirim dan penerima pesan. Perihal terdokumentasikannya tradisi lisan dalam bentuk tulisan, adalah tidak berpengaruh sama sekali terhadap esensi ataupun nilai dari "pola belajar mengajar" yang disampaikan dalam tradisi lisan. Hal ini senada dengan apa yang dikatakan oleh Ratna dalam Endraswara (2013: 69). Beliau mengatakan bahwa tradisi tulis tidak berpengaruh terhadap keberadaan sastra lisan. Artinya, meskipun tradisi lisan telah ditranskripsikan ke dalam tulisan, tradisi tersebut tetap hidup menurut mekanismenya masing-masing.

Kelokalan dalam sebuah tradisi lisan tidak dengan begitu saja dipersepsikan bahwa karya budaya tersebut adalah murni diciptakan dan dilaksanakan di daerah atau wilayah tersebut. Berbagai unsur budaya turut menyumbang terciptanya sebuah 
karya budaya. Dan, apakah unsur budaya tersebut juga adalah murni berasal dari daerah tersebut? Secara garis besar, Danandjaja mengatakan bahwa Indonesia memiliki karakteristik kebudayaan Melayu yang kemudian mendapat pengaruh dari kebudayaan Hindu Budha, Nasrani, dan Islam. Hindu Budha dalam pengertian Danandjaja lebih mengarah pada konteks penyebaran yang dilakukan oleh Kerajaan Majapahit (Danandjaja, 1977: 4-5). Berdasarkan pengertian tersebut, dapat dikatakan bahwa proses terciptanya unsur budaya di Indonesia mendapat pengaruh dari agama dan budaya yang dibawa oleh penyebar agama tersebut. Agama mengajarkan konsep ketuhanan dan budaya memperkaya konsep tersebut dengan berbagai unsur budaya pendukungnya. Hasil yang diperoleh di wilayah sebaran agama adalah terciptanya sebuah sistem kehidupan versi lokal yang menjadi pedoman dalam proses interaksi antara manusia - manusia, manusia - alam, dan manusia - Tuhan yang tersebar dalam berbagai unsur budaya di antaranya tradisi lisan.

Maca Syekh sebagai bagian dari tradisi lisan merupakan sebuah tradisi yang memiliki nilai penghormatan kepada Sang Pencipta melalui pembacaan riwayat perjalanan seorang Sufi. Teknis pembacaan dan ide untuk menciptakan tradisi lisan tersebut dilatarbelakangi oleh sejarah perjalanan kehidupan masyarakat Pandeglang yang memang menjadi salah satu bagian dari wilayah persebaran agama Islam di Indonesia.

Dalam proses penyebaran agama Islam di wilayah Kabupaten Pandeglang, unsur budaya lokal menjadi salah satu sarana yang dapat dikatakan cukup berpengaruh untuk menarik masyarakat agar tertarik, memahami, hingga menjadi pemeluk ajaran Agama Islam. Salah satu unsur budaya yang menjadi pilihan cara penyebaran agama Islam adalah tradisi lisan. Wilayah budaya Kabupaten Pandeglang dihuni oleh dua kelompok budaya yang cukup dominan, yaitu budaya
Sunda dan budaya Jawa. Akulturasi kedua budaya tersebut sudah terjadi sejak lama dan berjalan dengan harmonis. Salah satu bukti dari akulturasi tersebut adalah munculnya tradisi lisan Maca Syekh yang menganut dua bahasa, yaitu bahasa Sunda dan bahasa Jawa. Oleh karena itu, dapat ditarik dua bagian besar akulturasi tradisi lisan Maca Syekh, yaitu akulturasi dari unsur tradisi lisan, dan akulturasi dari unsur bahasa.

\section{- Akulturasi Tradisi}

Maca Syekh sebagai salah satu Warisan Budaya Takbenda (WBTB) telah dtetapkan sebagai Warisan Budaya Takbenda Indonesia pada tahun 2018 (Paluseri, dkk, 2018: 114-115) dimasukkan dalam kategori tradisi lisan. Wujud akulturasi Maca Syekh terkait dengan unsur tradisi lisan dapat dilihat dari kekayaan budaya lokal yang menjadi unsur terbentuknya Maca Syekh. Menurut Alamsyah P. (2018: 32-33), "Maca" dalam tradisi lisan Maca Syekh berasal dari kata wawacan, yaitu karya sastra naratif yang disusun dalam bentuk pupuh. Teks wawacan umumnya panjang karena isinya merupakan cerita. Selain itu, pelaku dalam wawacan jumlahnya relatif banyak, oleh karena itu pupuh yang digunakannya pun tidak hanya satu jenis. Karena wawacan tersebut berbentuk pupuh, maka teks wawacan disampaikan secara lisan dalam suatu pagelaran yang disebut beluk.

Di Kabupaten Majalengka, tradisi lisan yang mirip dengan Maca Syekh dinamakan gaok. Sementara untuk seni beluk itu sendiri tersebar di wilayah Tatar Sunda Parahyangan (Jawa Barat bagian Selatan). Seni beluk dan gaok dicirikan dengan alunan suara yang melengking. Berdasarkan penuturan informan, lengkingan suara tersebut dahulu kala difungsikan juga sebagai sebuah pemberitahuan kepada warga yang berada cukup jauh bahwa sedang dilaksanakan sebuah ritual atau kegiatan.

Maca Syekh yang dalam pelaksanaannya mirip dengan seni beluk, 
dalam beberapa hal terdapat perbedaan baik dari segi tatanan alunan suara, isi riwayat atau kisah maupun jumlah personilnya. Isi riwayat yang dilantunkan dalam seni beluk di antaranya kinanti, asmarandana, dangdanggula, sinom, pangkur, davina, lambung, ludrang. magatru, maskurnambang, gambuh, dangurisa. ${ }^{2}$ Sementara riwayat yang dibacakan dalam tradisi lisan Maca Syekh adalah tentang perilaku dan sepak terjang Syekh Abdul Qadir Jaelani semasa hidup sebagai salah seorang tokoh penyebar agama Islam.

Lantunan nada dan intonasi dalam Maca Syekh sekilas mirip dengan seseorang yang bercerita. Berbeda halnya dengan alunan suara yang melengking baik dalam seni beluk maupun gaok. Sementara untuk jumlah personil adalah tergantung dari tuan rumah yang hendak melaksanakan Maca Syekh. Apabila hanya dilakukan dalam waktu yang singkat, pelaku Maca Syekh cukup hanya satu orang saja. Sementara itu, durasi waktu yang panjang (dari isya hingga subuh) yang diminta oleh tuan rumah membuat personil Maca Syekh akan bertambah banyak.

Permintaan durasi waktu yang pendek oleh tuan rumah biasanya ditanggapi oleh pembaca Maca Syekh dengan melantunkan beberapa riwayat Syekh Abdul Qadir Jaelani yang sesuai dengan maksud dan tujuan sang tuan rumah. Sementara untuk durasi waktu yang panjang, pelantun riwayat Maca Syekh biasanya lebih dari seorang karena harus membaca seluruh riwayat Syekh Abdul Qadir Jaelani yang terbagi dalam 53 kisah. Adapun kisah atau riwayat tersebut adalah:

1. Kisah tentang nasab (asal usul dan keturunan) Syekh Abdul Qadir Jaelani.

2. Kisah tentang kelahiran Syekh Abdul Qadir Jaelani.

3. Kisah tentang masa belajar Syekh Abdul Qadir Jaelani.

2"Seni Beluk, dalam https://sites.google.com/site/nimusinstitut/senibeluk
4. Kisah tentang budi pekerti Syekh Abdul Qadir Jaelani.

5. Kisah tentang pakaian dan makanan Syekh Abdul Qadir Jaelani ketika menjadi santri.

6. Kisah pertemuan Syekh Abdul Qadir Jaelani dengan Nabi Hidir.

7. Kisah tentang peribadatan Syekh Abdul Qadir Jaelani.

8. Kisah tentang dasar-dasar perbuatan Syekh Abdul Qadir Jaelani.

9. Kisah penampilan Syekh Abdul Qadir Jaelani memberikan ceramah kepada manusia di atas kursi.

10. Kisah tentang perkumpulan seratus ulama Baghdad di tempat Syekh Abdul Qadir Jaelani yang membahas tentang berbagai masalah.

11. Kisah tentang telapak kaki Nabi Muhammad yang menginjak pundak Syekh Abdul Qadir Jaelani.

12. Kisah tentang kesaksian guru-guru sufi dan para wali tentang ketinggian martabat Syekh Abdul Qadir Jaelani.

13. Kisah tentang tercelanya orang yang menyebut Sayid Abdul Qadir tanpa punya wudlu.

14. Kisah tentang orang-orang yang memberi hadiah (bertawasul) kepada Syekh Abdul Qadir Jaelani akan tercapai maksudnya.

15. Kisah tentang nama-nama agung Sayid Abdul Qadir.

16. Kisah tentang Syekh Abdul Qadir Jaelani menghidupkan orang yang sudah meninggal dari alam kubur.

17. Kisah tentang Syekh Abdul Qadir Jaelani merebut nyawa pembantunya dari malaikat maut.

18. Kisah tentang kemampuan Syekh Abdul Qadir Jaelani dalam merubah anak perempuan jadi anak laki-laki.

19. Kisah tentang keselamatan (masuk surga) seorang fasik karena kecintaannya kepada Syekh Abdul Qadir al-Jaelani.

20. Kisah tentang kematian seekor burung yang terbang melewati Syekh Abdul Qadir Jaelani. 
21. Kisah tentang Syekh Abdul Qadir Jaelani menghidupkan seekor elang (alap-alap).

22. Kisah tentang Syekh Abdul Qadir Jaelani memerdekakan budak dan mengembalikan harta kekayaan.

23. Kisah tentang turunnya makanan dari langit.

24. Kisah tentang sembuhnya orang-orang yang kena penyakit "thoun" berkat memakan rerumputan dan meminum air dari madrasah milik Syekh Abdul Qadir Jaelani.

25. Kisah tentang Syeikh Abdul Qadir Jaelani menghidupkan ayam.

26. Kisah tentang anjing yang menunggu Istal (kadang kuda) setelah membunuh kucing.

27. Kisah tentang pembelian 40 kuda yang baik berdasarkan pengakuan kudakuda yang kurang sehat.

28. Kisah tentang Jin Ifrit yang berada di bawah kekuasaan Syekh Abdul Qadir Jaelani.

29. Kisah tentang ampunan raja jin terhadap orang yang membunuh putranya.

30. Kisah tentang Syekh Abdul Qadir Jaelani mengobati orang yang digoda jin.

31. Kisah tentang Syekh Abdul Qadir Jaelani mencium tangan Nabi Muhammad SAW.

32. Kisah tentang kemampuan Syekh Abdul Qadir Jaelani mengunjungi murid-muridnya di 70 tempat pada satu waktu.

33. Kisah tentang Syekh Abdul Qadir Jaelani menyelamatkan isteri salah seorang muridnya dari perbuatan tercela orang fasik.

34. Kisah tentang Syekh Abdul Qadir Jaelani menolong seorang yang akan dilepas kewaliannya.

35. Kisah tentang Syekh Ahmad Kanji menjadi Syekh Abdul Qadir Jaelani berdasarkan petunjuk gurunya.

36. Kisah tentang Syekh Ahmad Kanji mencari kayu bakar yang terbang ketika kayu itu akan diletakkan di atas kepalanya.

37. Kisah tentang salah seorang isteri yang dianugerahi berkat doanya Syekh Abdul Qadir Jaelani.

38. Kisah tentang Syekh Abdul Qadir Jaelani menyelamatkan muridnya dari siksa Munkar Nakir.

39. Kisah tentang Syekh Abdul Qadir Jaelani memberi ucapan selamat pada setiap tahun baru dan mencerita apa yang akan terjadi pada tahun berikutnya.

40. Kisah tentang Syekh Abdul Qadir Jaelani diberi lembaran buku untuk mencatat murid-muridnya yang datang pada hari kiamat.

41. Kisah tentang seorang yang mengisapjarinya, kemudian giginya tanpa merasa ingin makan (merasa kenyang).

42. Kisah tentang Syekh Shon 'Ani yang tidak taat kepada nasehat Sayid Abdul Qadir Jaelani.

43. Kisah tentang ikan sungai Dajlah (Tigris ?) yang berusaha mencium telapak tangannya.

44. Kisah tentang kemampuan Syekh Abdul Qadir Jaelani merubah wali mardud (ditolak) menjadi wali maqbul.

45. Kisah tentang Syekh Abdul Qadir Jaelani menyelamatkan muridnya dari api (siksa) dunia akhirat.

46. Kisah tentang Syaikh Abdul Qadir alJaelani menampakkan dirinya dalam wujud aki-aki (orang tua).

47. Kisah tentang Syekh Abdul Qadir Jaelani dicoba digoda setan.

48. Kisah tentang Syekh Abdul Qadir Jaelani menampar setan.

49. Kisah tentang pemberian hadiah uang dari seorang raja yang kemudian menjadi darah karena tidak diberikan secara langsung oleh raja.

50. Kisah tentang pemberian hadiah dari raja secara langsung berupa apel pada kesempatan yang lain.

51. Kisah tentang wasiat Syekh Abdul Qadir Jaelani kepada putranya. 
52. Kisah tentang salat hajat disertai dengan meminta pertolongan Syekh Abdul Qadir Jaelani, dan

53. Kisah tentang meninggalnya Syekh Abdul Qadir Jaelani (Alamsyah P., dkk, 2018: 61 - 64).

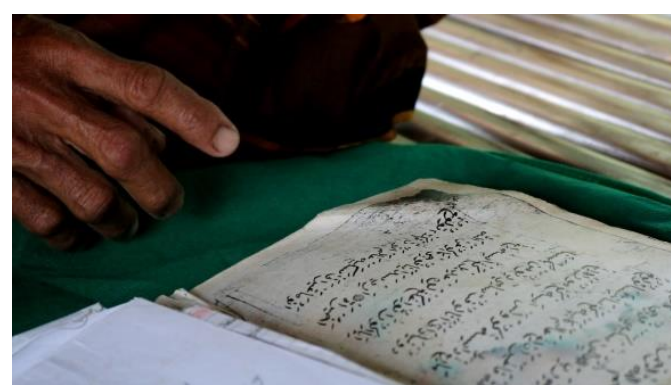

Gambar 1.Salah seorang penutur yang sedang melaksanakan tradisi lisan Maca Syekh Sumber: Data Primer, 2018.

Pada umumnya, acara Maca Syekh merupakan bagian dari acara slametan (selamatan), seperti acara khitanan, pernikahan, mengisi rumah baru, akan menempuh perjalanan jauh atau memiliki kendaraan baru. Meskipun tradisi tersebut semakin jarang dilakukan orang-orang yang hidup di perkotaan, tetapi bagi masyarakat di pedesaan acara Maca Syekh merupakan bagian tak terpisahkan dari ritual kehidupan mereka.

Kegiatan Maca Syekh bagi masyarakat Pandeglang dilakukan oleh orang perseorangan, seperti hendak mengadakan acara slametan (selamatan) untuk siklus kehidupan seseorang, seperti tujuh bulanan, khitanan dan pernikahan. Selain itu, kegiatan seperti ini ia lakukan setiap kali sedang atau akan melakukan pekerjaan yang dianggap mengandung resiko keselamatan dan sulit untuk mencapai tujuan seperti; pergi naik haji, mendirikan rumah dan membiayai anak sekolah (pendidikan). Kegiatan Maca Syekh, tidak hanya dilakukan pada saat ia menghadapi kesulitan tetapi juga dilaksanakan pada saat mendapat kebahagian dan kesuksesan seperti akan menempati rumah baru, mendapat kendaraan baru atau lulus ujian sekolah maupun kuliah. Kegiatan seperti ini dinamakan pula dengan syukuran.

Masyarakat yang menyelenggarakan acara Maca Syekh atau Wawacan Syekh Abdul Qadir Jaelani ini berkeyakinan akan mendapatkan keselamatan, keberkahan dan keinginannya tercapai. Ritual Maca Syekh yang mereka lakukan pada berbagai acara bertujuan meminta keselamatan dan tolak bala.

Dalam konsep Islam, keselamatan diartikan sebuah perbuatan atau tindakan yang akan, sedang, dan telah dilakukan didasarkan keselarasan suasana batin, rohani, hati yang baik dan sesuai dengan kehendak Allah swt. Selaras antara suasana hati dan perbuatan yang baik tersebut akan menuju pada apa yang disebut dengan insan kamil, yaitu sebutan untuk manusia yang nantinya akan selamat dunia dan akhirat. Syukuran ataupun pembacaan kitab suci Alquran secara berkelompok juga dilakukan setidaknya merupakan sebuah upaya dari tuan rumah agar apa yang akan, sedang, dan telah dilakukannya mendapat ridho dan ampunan dari Sang Maha Esa.

Tradisi Maca Syekh, bagi masyarakat Kabupaten Pandeglang memiliki makna sendiri dalam menghadapi berbagai tantangan dan kesulitan hidup. Mereka memiliki keyakinan bahwa menyelenggarakan Maca Syekh, baik di rumah secara rutin maupun dilaksanakan pada saat hajatan atau syukuran lainnya akan mendatangkan keberkahan dan keselamatan. Karena itu mereka secara rutin menyelenggarakan acara Maca Syekh setiap kali akan menghadapi berbagai tantangan dan kesulitan.

Pada umumnya acara Maca Syekh berlangsung pada malam hari, dari setelah salat isya sampai subuh, meskipun tidak jarang dilakukan pada pagi atau siang hari. Sebelum acara Maca Syekh, biasanya tuan rumah terlebih dahulu menyediakan semacam "sesajen'. Sesajen tersebut dimaksudkan sebagai persyaratan, agar saat berlangsungnya Maca Syekh dapat berlangsung dengan lancar sesuai dengan 
yang diharapkan. Biasanya sesajen yang harus disediakan adalah: kopi pahit, kopi manis, kembang tujuh macam, kue tujuh macam - yang dikenal dengan istilah perwanten, beberapa batang rokok, kemenyan, wadah kecil yang berisi air dan uang logam.

Perihal uang logam dalam wadah kecil berisi air yang menjadi salah satu syarat pelaksanaan tradisi lisan Maca Syekh, juga ada beberapa kesamaan dengan tradisi serupa di wilayah lainnya, seperti ketika berkunjung ke leuweung larangan masyarakat Kampung Kuta Kabupaten Ciamis juga disyaratkan untuk menaruh atau melempar uang logam dalam sebuah kubangan yang ada dalam leuweung larangan tersebut. Mereka masih mempercayai bahwa pemberian uang logam menjadi salah satu syarat "pemberian" kepada Yang Maha Kuasa.

Tersebut dalam beberapa barang yang ada dalam sesajen di atas, juga sebenarnya bukan spesifik atau hanya ada dalam syarat sesajen dalam tradisi lisan Maca Syekh, seperti beberapa batang rokok, kemenyan, kopi pahit, kopi manis, kembang tujuh macam, kue tujuh. Menurut Ki Demang Wangsafyudin ${ }^{3}$, bahan-bahan tersebut merupakan sebentuk alat ritual yang banyak ditemukan pada masyarakat budaya Sunda dan Jawa. Beberapa perlambang dalam bahan sesajen tersebut dikatakan bahwa kemenyan memiliki makna mengkaji dan menghayati serta menelusuri hakekat dari nilai-nilai $\mathrm{Ke}$ Tuhanan harus dilakukan secara sungguhsungguh dan sebenar-benarnya. Kopi pahit dan kopi manis melambangkan kehidupan yang berjalan sering tidak sesuai dengan keinginan. Kembang dan kue tujuh macam melambangkan tujuh kuasa Tuhan (Hyang) yaitu Kawasa, Kersa, Uninga, Hirup, Tingali, Ngarungu, dan Ngandika.

\footnotetext{
${ }^{3}$ Mustafid Sawunggalih,"Makna Sesajen”, dalam https://www.kompasiana.com/mustafid/54ff908 7a333116a4a51084e/makna-sesajen26 Juni 2015 17:29
}

Sesajen yang dilakukan sebagai salah satu syarat dalam pelaksanaan tradisi lisan Maca Syekh menurut sebagian kalangan dianggap sebagai sebuah perbuatan syirik. Hal tersebut juga telah tercantum dalam Alquran surat AlAn'ām/6 : 136, yang artinya:

"Dan mereka memperuntukkan bagi Allah satu bagian dari tanaman dan ternak yang telah diciptakan Allah, lalu mereka berkata sesuai dengan persangkaan mereka: "Ini untuk Allah dan ini untuk berhala-berhala kami." Maka saji-sajian yang diperuntukkan bagi berhala-berhala mereka tidak sampai kepada Allah; dan saji-sajian yang diperuntukkan bagi Allah, maka sajian itu sampai kepada berhala berhala mereka. Amat buruklah ketetapan mereka itu”( Al-An'ām/6 : 136)

Sebuah tradisi mensyaratkan adanya beberapa kepentingan yang mengharuskan terjadinya sebuah momen persembahan agar apa yang diinginkannya dapat tercapai dengan baik. Keinginan tersebut merupakan sebuah niatan baik dan tidak ingin menimbulkan konflik dengan sekelompok masyarakat, aliran, maupun ajaran yang menghendaki pelarangan terhadap segala bentuk sesajen. Pelaksanaan. Pemenuhan syarat berupa sesajen dalam tradisi lisan Maca Syekh lebih disebabkan pada unsur keinginan untuk tidak melupakan tradisi yang telah berjalan turun temurun.

Beberapa mitos yang hingga kini sebagian masih dipercayai oleh masyarakat seperti kewajiban tuan rumah untuk menyediakan "sesajen" secara lengkap pada saat Maca Syekh, pelaku Maca Syekh, yang sering dimintai oleh warga untuk membaca Maca Syekh di rumahnya. Menurutnya ketidaklengkapan sesajen yang disediakan pada saat Maca Syekh akan mengakibatkan adanya gangguan saat acara sedang berlangsung. Misalnya, alat pengeras suara (loudspeaker) yang jatuh berulang-ulang. Hal tersebut menurut 
masyarakat setempat disebabkan oleh penyediaan sesaji oleh tuan rumah sesaji yang kurang lengkap.

Perihal kepercayaan atau adanya unsur kecelakaan atau akibat buruk yang nantinya akan terjadi apabila tidak melaksanakan pemenuhan syarat tersebut lebih dianggap sebagai mitos yang hingga kini masih diyakini oleh sebagian masyarakat. Mitos tersebut kini lebih diarahkan pada sikap personal dan tidak lebih dari bagian dari upaya yang dianggap tidak wajar untuk menjaga tradisi tetap berlangsung.

Beranjak dari adanya unsur budaya lokal yang diadopsi dan menjadikan sebuah paduan akulturasi yang serasi dalam tradisi lisan Maca Syekh, dapat menjadi sebuah pola yang sebenarnya akan berjalan lancar apabila kelompok masyarakat dari unsur agama (Islam) dengan kelompok masyarakat dari unsur budaya mengambil nilai budaya luhur dari kedua sisi sehingga persepsi yang mengerucut adalah sebuah kehidupan dengan tatanan perilaku yang akan membawa keharmonisan dengan berpedoman pada Ketuhanan Yang Maha Kuasa.

\section{- Akulturasi Bahasa}

Syekh Abdul Qadir Jaelani sebagai sebagai seorang tokoh dengan sosok yang mampu "menghipnotis" umat manusia dengan bersandar pada keteladanan dan kecintaannya pada Islam, dalam perjalanan ajarannya telah banyak menciptakan banyak kekayaan budaya yang mengacu pada sepak terjang semasa hidupnya. Maca Syekh adalah salah satu di antaranya. Sebuah kekayaan budaya yang hingga kini masih dipraktikkan oleh sebagian masyarakat di Kabupaten Pandeglang yang notabene merupakan masyarakat hasil akulturasi budaya Jawa dan Sunda.

Kerinduan dan keinginan untuk mengenang sepak terjang Syekh Abdul Qadir Jaelani dilakukan teknik dan cara beragam. Salah satu dari upaya tersebut adalah dengan mengadopsi seni beluk.
Seperti yang telah dijelaskan di atas bahwa sumber dari seni ini adalah pembacaan hikayat atau riwayat tokoh budaya yang dilantunkan dengan nada tinggi. Hasil dari adopsi ini adalah dengan mengganti riwayat tersebut dengan riwayat Syekh Abdul Qadir Jaelani. Menariknya adalah bahwa bahasa Arab yang menjadi sumber riwayat beliau diterjemahkan dalam dua bahasa yaitu bahasa Jawa dan bahasa Sunda. Unsur "keAraban" agar tidak hilang namun dalam pembacaannya dapat dimengerti oleh masyarakat awam kemudian diantisipasi dengan cara menuliskan riwayat tersebut dengan menggunakan huruf Arab Pegon.

\begin{tabular}{|c|c|c|c|}
\hline No. & Bunyi & Jawa & Pegon \\
\hline 1. & ha & in & $011^{3}$ \\
\hline 2. & na & मी & ن \\
\hline 3. & ca & ar & ج \\
\hline 4. & ra & $n$ & J \\
\hline 5. & $\mathrm{ka}$ & m & ك \\
\hline 6. & da & a & د \\
\hline 7. & ta & inn & $ت$ \\
\hline 8. & $\mathrm{sa}$ & aA & س \\
\hline 9. & wa & תו & g \\
\hline 10. & la & m & J \\
\hline 11. & pa & तI & ف \\
\hline 12. & dha & ar & د \\
\hline 13. & ja & aKK & ج \\
\hline 14. & ya & aก & ي \\
\hline 15. & nya & $\mathrm{am}$ & ي \\
\hline 16. & $\mathrm{ma}$ & धת & 5 \\
\hline 17. & ga & $m$ & 5 \\
\hline 18. & $\mathrm{ba}$ & $\mathrm{an}$ & ب \\
\hline 19. & tha & นุา & b \\
\hline 20. & nga & חา & $\varepsilon$ \\
\hline
\end{tabular}

Gambar 2. Arab Pegon

Sumber: Pudjiastuti, (2009: 273-274). 
Unsur kebahasaan pada masyarakat Pandeglang pada umumnya adalah bahasa Sunda. Masyarakat Jawa yang sudah ada di Provinsi Banten sejak zaman dahulu melakukan proses akulturasi dengan mengutamakan penguasaan bahasa Sunda terlebih dahulu. Akan halnya dengan masyarakat Sunda setelah sekian lama berinteraksi dengan masyarakat Jawa menyebabkan perubahan dialek Sunda hingga terciptalah apa yang biasa disebut dengan istilah Sunda Banten. Menurut Tihami (2004: 2) bahasa Sunda merupakan bahasa masyarakat Banten Girang yang sudah lama ada dan dipergunakan jauh sebelum kedatangan Syarif Hidayatullah. Bahasa Jawa merupakan pengaruh dari kedatangan Syarif Hidayatullah dan puteranya bernama Hasanuddin di Banten yang kemudian disandingkan dengan proses penyebaran agama Islam.

Proses akulturasi terus berjalan mengarah ke bidang lainnya, yaitu dalam bidang tradisi lisan yaitu dengan mengemukanya pembacaan riwayat Syekh Abdul Qadir Jaelani menggunakan dua buah versi bahasa yaitu bahasa Jawa dan bahasa Sunda.

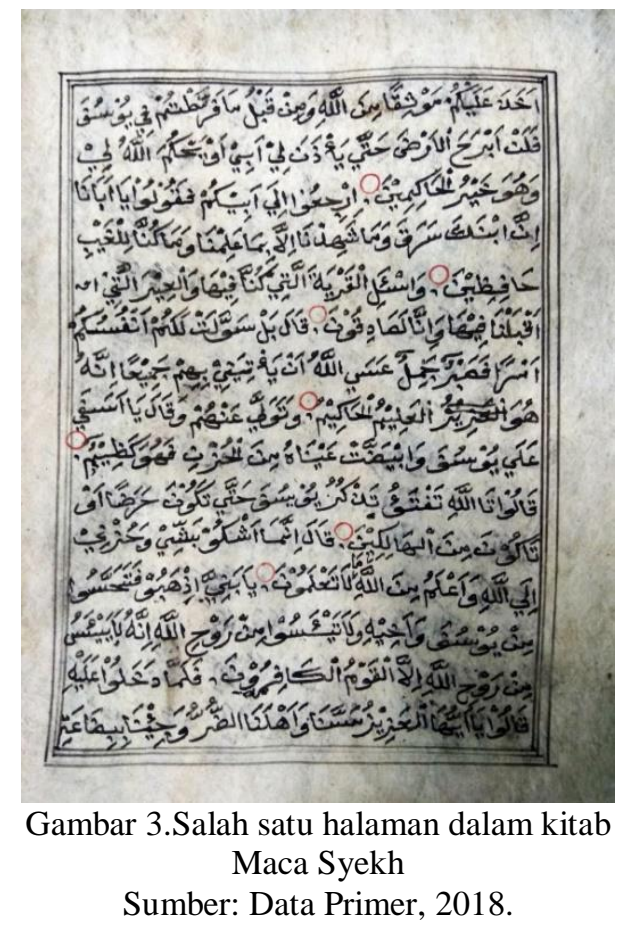

Perihal tulisan dalam riwayat Syekh Abdul Qadir Jaelani yang diungkapkan dalam dua bahasa (Jawa dan Sunda) secara tidak langsung mengacu pada sumber dari huruf dalam bacaan tersebut, yaitu huruf Arab Pegon. Menurut Behrend dalam Pudjiastuti (2009: 272), huruf Arab Pegon diciptakan untuk mempermudah pembacaan huruf Arab yang disesuaikan dengan karakter lidah (logat) bahasa Jawa. Proses ini dapat dianggap sebagai salah satu solusi dalam proses kelancaran penyebaran agama Islam di wilayah budaya Jawa dengan konsentrasi penyebaran pada pondok-pondok pesantren.

Riwayat Syekh Abdul Qadir Jaelani yang ditulis menggunakan huruf Arab Pegon tidak begitu saja tercipta tanpa ada latar belakangnya. Tihami (2004: 3) mengemukakan bahwa penyebab utama penggunaan bahasa Jawa dan Sunda yang ditulis menggunakan hurub Arab Pegon erat kaitannya dengan masa penjajahan Belanda. Kala itu, huruf Arab menjadi simbol dari sarana komunikasi kalangan kaum modernis, sementara pihak kolonial menggunakan aksara Jawa. Penggunaan huruf Arab kemudian menjadi bagian utama dalam setiap gerakan kaum maju kala itu. Akan halnya dengan pengaruh penulisan Arab Pegon pada kaum lama, menurut Tessier (1999: 173) bahwa huruf Arab Pegon menjadi bagian dari perjalanan penyebaran agama Islam yang dapat dipergunakan dalam kaitannya dengan proses komunikasi, pemberitahuan tertulis maupun penulisan yang tidak terlalu berada dalam konteks Alquran, termasuk di dalamnya adalah menggunakan huruf Arab Pegon dalam penulisan riwayat Syekh Abdul Qadir Jaelani. Hal ini diperkuat oleh Pudjiastuti (2009: 277-280) yang mengatakan bahwa penggunaan tulisan Arab Pegon tidak secara spesifik pada isi dan maksud yang bersifat keislaman melainkan dapat dipergunakan dalam berbagai fungsi, di antaranya:

- Sarana penulisan teks keagamaan

- Sarana penulisan teks sastra 
- Sarana penulisan surat menyurat

- Sarana penulisan teks mantra

Sarana penulisan teks keagamaan dalam pengertian bahwa bahasa Arab sebagai bahasa baku dalam Alquran dan hadis, pada tradisi lisan Maca Syekh menggunakan bahasa Jawa dan Sunda dengan tujuan agar apa yang dibacakan oleh penutur Maca Syekh langsung dapat dimengerti dan dipahami.

Menyimak dari penjelasan di atas dapat dikatakan bahwa akulturasi bahasa dalam tradisi lisan Maca Syekh merupakan salah satu bentuk dari sebuah perjalanan budaya yang sangat panjang dan membutuhkan waktu lama untuk menuju pada terciptanya sebuah formulasi kekayaan budaya yang dapat diterima oleh semua pihak.

\section{PENUTUP}

Syekh Abdul Qadir Jaelani yang menjadi salah satu tokoh populer agama Islam telah banyak mempengaruhi kebudayaan lokal dalam proses perjalanan penyebaran agama Islam. Sebagian masyarakat mendapatkan ajaran Islam dan kemudian memeluk agama Islam, dan sebagian lainnya menjadikan sosok Syekh Abdul Qadir Jaelani sebagai sosok sufi yang patut diteladani perjalanan hidupnya.

Banyak cara dilakukan untuk mengenang, mendengarkan kisah, dan mengikuti pola hidup Syekh Abdul Qadir Jaelani dengan berbagai cara, salah satunya dengan mendengarkan tuturan riwayat hidup Syekh Abdul Qadir Jaelani melalui tradisi lisan Maca Syekh seperti yang dilakukan oleh sebagian masyarakat di Kabupaten Pandeglang.

Hal menarik dari Maca Syekh adalah bahwa ditemukan sebuah proses akulturasi tradisi dan bahasa yang terasa kental dalam setiap pelaksanaan Maca Syekh. Percampuran antara budaya Sunda, Jawa, dan budaya Arab tempat Syekh Abdul Qadir Jaelani berkiprah membuat Maca Syekh menjadi semacam produk akulturasi dari multi budaya.
Unsur bahasa yang menjadi unsur terpenting dari pembacaan riwayat Syekh Abdul Qadir Jaelani merupakan sebuah produk akulturasi yang tercipta dengan turut melibatkan unsur politik yang dalam proses perjalanannya berakhir dengan harmonis dan hingga kini dapat menjadi bagian dari kehidupan budaya masyarakat Pandeglang yang juga merupakan produk akulturasi dari budaya masyarakat Jawa dan Sunda.

Di akhir tulisan ini, perihal adanya unsur kepercayaan dalam pengadaan bahan ritual tradisi lisan Maca Syekh harus ditanggapi dengan menggunakan berbagai unsur yang mengacu upaya pelestarian nilai budaya luhur sehingga akan menghasilkan sebuah kesepakatan yang akan menambah penguatan karakter kebangsaan.

\section{DAFTAR SUMBER}

\section{Makalah, Laporan Penelitian, Skripsi, Tesis, dan Jurnal}

Alamsyah P., Suwardi, Lina Herlinawati, Irvan Setiawan, Yanti Nisfiyanti, 2018, "Kajian Nilai Pada Tradisi Maca Syekh di Kabupaten Pandeglang Provinsi Banten", Laporan Pengkajian Nilai Budaya, Bandung: Balai Pelestarian Nilai Budaya Jawa Barat.

Danandjaja, James, 1977.

Kebudayaan Petani Desa Trunyan di Bali: Satu Lukisan Analitis yang Menghubungkan Praktek Pengasuhan Anak Orang Trunyan dengan Latar Belakang Etnografinya, Thesis, Jakarta: Jurusan Antropologi Budaya, Universitas Indonesia.

Dwi Aprilyanto, Agung. 2015.

Spiritualitas Pemuda Urban (Peran Manaqib Syekh Abdul Qadir al-Jilani di Pondok Pesantren Aitam Nurul Karomah terhadap Pembentukan Spiritualitas Pemuda Kendangsari Surabaya). Skripsi. Surabaya: Prodi Filsafat Agama Fakultas Ushuluddin dan Filsafat Universitas Islam Negeri Sunan Ampel Surabaya.

Oetomo, Dede. "Penelitian Kualitatif: Aliran dan Tema", dalam Bagong Suyanto dan Sutinah (ed), Metode Penelitian Sosial: 
Berbagai Alternatif Pendekatan. Jakarta: Kencana. 2005.

Praharani, Ruli. 2007.

Wayang Kulit sebagai Media Penyebaran Agama Islam di Demak pada Abad Ke$X V$.Skripsi. Yogyakarta: Program Studi Pendidikan Sejarah Jurusan Pendidikan Ilmu Pengetahuan Sosial Fakultas Keguruan dan Ilmu Pendidikan Universitas Sanata Dharma Yogyakarta.

Pudjiastuti, Titik. "Tulisan PegonWujud Identitas Islam-JawaTinjauan atas Bentuk dan Fungsinya", dalam Jurnal Suhuf, Vol. 2, No. 2, 2009.

Sedyawati, Edi. "Kedudukan Tradisi Lisan dalam Ilmu-ilmu Sosial dan Ilmu Budaya", dalam Warta ATL. Jurnal Pengetahuan dan Komunikasi Peneliti dan Pemerhati Tradisi Lisan, Edisi Maret 1996.

Kumalasari, Devi Senja. 2017.

Sejarah Perkembangan Jamaah Manaqib Syaikh Abdul Qodir Jailani Di Pondok Pesantren Al- Qodiri Kec. Gebang Kab. Jember (1997-2015). Skripsi. Surabaya: Fakultas Adab Universitas Islam Negeri (UIN) Sunan Ampel Surabaya.

Tihami, M.A. "Khazanah Kebudayaan Banten", Makalah, dalam Seminar Sejarah dan Kebudayaan Banten, Pusat Kajian Sejarah dan Budaya STAIN "SMHB" Serang, 1 Juli 2004.

\section{Buku}

Anwar, Rosihon. 2005.

Kamus Tasawuf Jilid 2, Bandung: PT. Remaja Rosdakarya.

BPS Kabupaten Pandeglang. 2017.

Kabupaten Pandeglang dalam Angka 2017, Pandeglang: BPS Kabupaten Pandeglang.

Endraswara, Suwardi. 2013. Metodologi Antropologi Sastra, Yogyakarta: Penerbit Ombak.

Hamka, 1996. Tasawuf Modern, Jakarta: Pustaka Panji Mas.

Harwantiyoko dan Neltje F. Katuuk, 1992. Pengantar Sosiologi dan Ilmu Sosial Dasar, Jakarta: Gunadarma.
Ihromi, T.O., (ed). 2006.

Pokok-pokok Antropologi Budaya, Jakarta: Yayasan Obor Indonesia.

Koentjaraningrat. 1990. Metode-Metode Penelitian Masyarakat. Jakarta: Pustaka Jaya.

Mahjudin. 1991. Kuliah Akhlaq Tasawuf. Jakarta: Kalam Mulia.

Paluseri, Dais Dharmawan, dkk. 2018.

Penetapan Warisan Budaya Takbenda Indonesia Tahun 2018, Jakarta: Direktorat Warisan dan Diplomasi Budaya, Direktorat Jenderal Kebudayaan, Kementerian Pendidikan dan Kebudayaan.

Tessier. 1999.

Pusat Pengajaran Tradisional Agama Islam di Jawa Barat dan Peranannya dalam Sejarah Perjuangan, Cilegon: Yayasan Ki Wasid.

Waluyo, Harry, dkk. 2009.

Buku Panduan Praktis Pencatatan Warisan Budaya Takbenda Indonesia, Jakarta: Departemen Kebudayaan dan Pariwisata Republik Indonesia dan Kantor UNESCO Jakarta.

Zulaeha, Ida. 2010

Dialektologi: Dialek Geografi dan Dialek Sosial. Jogjakarta: Graha Ilmu.

\section{Website}

Anonim. "Seni Beluk, dalam https://sites.google.com/site/nimusinstit ut/seni-beluk.

Mustafid Sawunggalih. "Makna Sesajen", dalam https://www.kompasiana. com/ mustafid/54ff9087a333116a4a51084e/m akna-sesajen diakses 26 Juni 2015 17:29. 